\title{
Neonatal Vitamin D status and the risk of neonatal sepsis
}

\author{
Abdurrahman Avar Ozdemir' ${ }^{1}$ Yakup Cag ${ }^{2}$
}

\begin{abstract}
Objective: To evaluate the maternal and neonatal 25-hydroxyvitamin $D[25(\mathrm{OH}) \mathrm{D}]$ levels and the effect of 25(OH)D levels on the development of neonatal sepsis.

Methods: This prospective study was performed in the neonatal intensive care unit of Medicine Hospital/ Biruni University between November 2017 and September 2018. Fifty one term infants with sepsis group and 56 term infants with control group were included in this study. Blood samples for whole blood count, CRP, Ca, P, ALP, 25(OH)D and culture were obtained from all neonates.

Results: Mean vitamin $D$ levels for the neonates and their mothers were found to be $12.4 \pm 8.5 \mathrm{ng} / \mathrm{ml}$ and $13 \pm 8.7 \mathrm{ng} / \mathrm{ml}$, respectively. There was a significant correlation between maternal and newborn $25(\mathrm{OH})$ $D$ levels $(r=0.72, p<0.01)$. The number of the newborns with vitamin $D$ deficiency was significantly higher in the sepsis group $(n=31,60.8 \%)$ than in the control group $(n=30,53.6 \% ; p=0.00)$, corresponding to significantly lower levels of vitamin $D$ in the sepsis group $(11 \pm 5.5 \mathrm{ng} / \mathrm{ml} v \mathrm{vs} .13 .8 \pm 10.6 \mathrm{ng} / \mathrm{ml} ; \mathrm{p}=0.012)$. Similarly, maternal vitamin $D$ levels was significantly lower in the sepsis group than in the control group $(10.8 \pm 5.6 \mathrm{ng} / \mathrm{ml}$ vs. $14.9 \pm 10 \mathrm{ng} / \mathrm{ml} ; \mathrm{p}=0.001)$.

Conclusion: Our findings suggest that there may be an association between vitamin $\mathrm{D}$ deficiency and neonatal sepsis.
\end{abstract}

KEYWORDS: Vitamin D, Sepsis, Neonate.

doi: https://doi.org/10.12669/pjms.35.2.342

How to cite this:

Ozdemir AA, Cag Y. Neonatal Vitamin D status and the risk of neonatal sepsis. Pak J Med Sci. 2019;35(2):420-425. doi: https://doi.org/10.12669/pjms.35.2.342

This is an Open Access article distributed under the terms of the Creative Commons Attribution License (http://creativecommons.org/licenses/by/3.0), which permits unrestricted use, distribution, and reproduction in any medium, provided the original work is properly cited.

1. Abdurrahman Avar Ozdemir

Department of Pediatrics,

Medicine Hospital,

Biruni University,

Istanbul, Turkey.

2. Yakup Cag

Department of Pediatrics,

Dr. Lutfi Kirdar Training and Research Hospital,

Medical Sciences University,

Istanbul, Turkey.

Correspondence:

Abdurrahman Avar Ozdemir, MD,

Department of Pediatrics,

Medicine Hospital,

Biruni University

Barbaros Mah. Hoca Ahmed Yesevi Cad. No: 149,

Gunesli-Bagcilar-Istanbul,

Postal Code: 34203, Turkey.

E-mail: avarozdemir@gmail.com

* Received for Publication: October 24, 2018

* Revision Received: January 9, 2019

* Revision Accepted: January 15, 2019

\section{INTRODUCTION}

Vitamin $\mathrm{D}$ is a lipid-soluble prohormone produced in the human skin exposure to ultraviolet radiation. It plays an important role in calcium and phosphorus homeostasis., ${ }^{1,2}$ Although its deficiency is generally linked to the disorders of bone mineralization, there is some evidence suggesting that vitamin $\mathrm{D}$ also plays a role in the immune function. ${ }^{3,4}$ Vitamin D receptors are widely expressed in the epithelial tissue and cells of the immune system. 1,25-dihydroxyvitamin D $(1,25(\mathrm{OH}) 2 \mathrm{D})$, an active form of vitamin $\mathrm{D}$, acts as an immune modulator to stimulates the innate immune system. ${ }^{3,4}$

In several studies of adults low vitamin D levels have been found to be associated with predisposition to sepsis. ${ }^{5,6}$ Similarly, in some studies of children, 
significant associations have been shown between vitamin $\mathrm{D}$ deficiency and respiratory tract infections and sepsis. ${ }^{7,8}$ However, there are limited data on the role of vitamin D in neonatal sepsis. Neonatal sepsis refers to bacteremia and associated clinical signs and symptoms occurring in the first month of life. ${ }^{9,10}$ It is among the leading causes of morbidity and mortality in newborns. As the immune system of newborns has not fully developed at birth, they are relatively immunocompromised, rendering them vulnerable to infections. ${ }^{11}$

In this prospective study, we aimed to evaluate the maternal and neonatal vitamin D status and the effect of vitamin D levels on the development of neonatal sepsis.

\section{METHODS}

This prospective study was performed in the neonatal intensive care unit of Medicine Hospital/ Biruni University between November 2017 and September 2018. The study protocol was approved by the ethics committee of university and informed written consent was obtained from all mothers.

Exclusion criteria for newborns included the presence of the following: congenital malformation or disease, metabolic disease, small for gestational age (SGA), prematurity, twin neonates, use of antibiotic therapy at admission, and age above 28 days. Exclusion criteria for mothers included malnutrition, metabolic or chronic disease, twin pregnancy, use of medications, chorioamnionitis, premature rupture of membrans, and age less than 20 years or above 40 years.

The study group comprised term newborns with laboratory and clinical findings of sepsis, which was further categorized as early onset (EOS; within $\leq 3$ days of birth) or late onset (LOS; after three days of birth) neonatal sepsis. Demographic features including gestational age, gender, weight, mode of delivery, Apgar score, season and prenatal findings were recorded. Blood samples for the whole blood count, C-reactive protein (CRP), and culture were obtained from all neonates with suspected sepsis at admission and the hematologic parameters were evaluated according to the Manroe and Rodwell scoring systems. ${ }^{12,13}$ The neonates were categorized into 4 groups (highly probable sepsis; Group-I, probable sepsis; Group-II, possible sepsis; GroupIII and no sepsis; Group-IV) according to the criteria defined by Gitto et al. ${ }^{14}$ The newborns in groups 1,2 and 3 were called as sepsis group and others with no signs of neonatal sepsis served as the control group, which consisted of infants diagnosed with transient tachypnea of the newborn (TTN) or neonatal hyperbilirubinemia.

Demographic features of the mothers such as age, gender, parity, socio-economic status, education level, and the factors associated with their vitamin D status (sun exposure, vitamin D intake, style of clothing and season) were recorded. Wearing traditional clothes covering the arms, legs and head was accepted a covered clothing style. Limited exposure to sunlight was considered to spend less than 30 minutes outside during the day. The mothers were also classified into three groups according to their daily vitamin D intake: none, insufficient (irregular or low-dose) and sufficient. In Turkey, a vitamin D supplementation program has been in operation, with daily provision of 1200 IU vitamin D to all pregnant women from the first trimester until six months after delivery.

Blood samples for calcium $(\mathrm{Ca})$, phosphorus $(\mathrm{P})$, alkaline phosphatase (ALP) and 25(OH)D were obtained from all participants at admission. The $25(\mathrm{OH}) \mathrm{D}$ levels were measured by an enzymelinked fluorescent assay on the Architect i2000SR analyzer (Abbott Laboratories, US) and the Ca, $\mathrm{P}, \mathrm{ALP}$ and CRP levels were measured using the photometry method on the Architect $\mathrm{C} 8000$ analyzer (Abbott Laboratories, U.S.A). Complete blood count measurements were performed by using th Cell-Dyn Ruby System (Abbott Laboratories, US). $25(\mathrm{OH})$ vitamin D levels were classified according to the guidelines of the Endocrine Society; as sufficient for $>20 \mathrm{ng} / \mathrm{ml}(>50 \mathrm{nmol} / 1)$, insufficiency for $12-20 \mathrm{ng} / \mathrm{ml}(30-50 \mathrm{nmol} / \mathrm{l})$, and deficiency for $<12 \mathrm{ng} / \mathrm{ml}(30 \mathrm{nmol} / \mathrm{l})$. The participants were classified into 3 group's accordingly. ${ }^{15}$

Data were analyzed using the SPSS Statistics 20 program. Descriptive variables were expressed as mean, median, standard deviation, minimum, maximum and percentages. Between group differences were evaluated usingStudent's-t test, Chi squared test, Mann-Whitney U test and correlations between quantitative data were analyzed by the Spearman's correlation test. A $p$ value of less than 0.05 was considered to be significant.

\section{RESULTS}

This study included 107 term neonates (41 females, 66 males), of which $51(47.7 \%)$ were in the sepsis group and $56(52.3 \%)$ were in the control group. The mean gestational age was $38 \pm 1.3$ weeks, and the mean birth weight was $3.338 \pm 482 \mathrm{~g}$. There were no significant differences between the two groups with regard to gestation week, birth weight, 
Table-I: Clinical characteristics of the newborns with or without sepsis.

\begin{tabular}{|c|c|c|c|}
\hline & $\begin{array}{l}\text { Sepsis Group }(n=51) \\
(\text { Mean } \pm S D)\end{array}$ & $\begin{array}{c}\text { Control Group }(n=56) \\
(\text { Mean } \pm S D)\end{array}$ & $p$ \\
\hline Gestational Age (week) & $38.1 \pm 1.5$ & $38.2 \pm 0.9$ & ${ }^{1} 0.74$ \\
\hline \multicolumn{4}{|l|}{ Gender } \\
\hline Female & $11(21.6 \%)$ & $30(53.6 \%)$ & \multirow{2}{*}{${ }^{2} 0.01^{*}$} \\
\hline Male & $40(78.4 \%)$ & $26(46.4 \%)$ & \\
\hline Birth weight (g) & $3346 \pm 574$ & $3331 \pm 401$ & ${ }^{1} 0.43$ \\
\hline \multicolumn{4}{|l|}{ Delivery route } \\
\hline Normal & $41(80.4 \%)$ & $36(64.3 \%)$ & \multirow{2}{*}{${ }^{2} 0.06$} \\
\hline Cesarean & $10(19.6 \%)$ & $20(35.7 \%)$ & \\
\hline Apgar score min.1 & $8 \pm 1$ & $8 \pm 1$ & ${ }^{1} 0.7$ \\
\hline Apgar score min. 5 & $9 \pm 1$ & $9 \pm 1$ & ${ }^{1} 0.6$ \\
\hline CRP (mg/L) & $17.9 \pm 15$ & $1.9 \pm 2.1$ & ${ }^{1} 0.001^{*}$ \\
\hline Leukocyte (/mm & $16278 \pm 6782$ & $17841 \pm 6999$ & ${ }^{1} 0.32$ \\
\hline Platelet (/mm³) & $224989 \pm 103104$ & $266916 \pm 66060$ & ${ }^{1} 0.04^{* *}$ \\
\hline
\end{tabular}

*Statistically significant at $0.01, * *$ Statistically significant at 0.05 ;

1: Student's t-test 2: Chi-squared test.

type of delivery, and Apgar score. The number of male newborns was significantly higher in the sepsis group $(p=0.01)$. The newborns in the sepsis group had significantly higher CRP levels $(p=0.001)$ and significantly lower platelet counts $(p=0.04)$ (Table-I).

The mothers of the newborns in the two groups did not differ significantly with regard to age, number of births, socio-economic level, daily sun exposure, and style of clothing. The number of the mothers who took vitamin D during pregnancy was higher in the control group than in the sepsis group $(p=0.02)$. Based on the seasonal distribution of deliveries, the number or winter deliveries was significantly higher in the sepsis group $(p=0.016)$ (Table-II).

Overall, the mean $25(\mathrm{OH}) \mathrm{D}$ level was $12.4 \pm 8.5 \mathrm{ng} /$ $\mathrm{ml}$ in the infants and $13 \pm 8.7 \mathrm{ng} / \mathrm{ml}$ in the mothers, with a significant correlation between maternal and infant 25(OH)D levels $(\mathrm{r}=0.72, \mathrm{p}<0.01)$. Vitamin $\mathrm{D}$ deficiency was detected in 61 newborns (57\%) and in 55 mothers (51.4\%). The number of the newborns with vitamin D deficiency was significantly higher in the sepsis group $(n=31,60.8 \%)$ than in the control group $(n=30,53.6 \% ; p=0.00)$, corresponding to significantly lower levels of vitamin $\mathrm{D}$ in the sepsis group $(11 \pm 5.5 \mathrm{ng} / \mathrm{ml}$ vs. $13.8 \pm 10.6 \mathrm{ng} / \mathrm{ml}$; $\mathrm{p}=0.012$ ). Similarly, maternal vitamin D levels was significantly lower in the sepsis group than in the control group $(10.8 \pm 5.6 \mathrm{ng} / \mathrm{ml}$ vs. $14.9 \pm 10 \mathrm{ng} / \mathrm{ml}$; $\mathrm{p}=0.001)$. Other laboratory newborn and maternal markers including $\mathrm{Ca}, \mathrm{P}$ and ALP were similar in the two groups (Table-III, IV).

Of 51 newborns with sepsis, 39 (76.5\%) and 12 (23.5\%) newborns were identified as having EOS and LOS, respectively. The newborns with EOS $(10.4 \pm 5.7 \mathrm{ng} / \mathrm{ml})$ had lower vitamin D levels than those with LOS $(12.8 \pm 4.3 \mathrm{ng} / \mathrm{ml})$, but the difference did not reach statistical significance $(p=0.075)$. However, the mean vitamin D level of the newborns with EOS significantly differed from that of the control group $(p=0.02)$, which was not the case for the newborns with LOS $(p=0.7)$. The mean vitamin $D$ levels were similar among patients with positive $(\mathrm{n}=11 ; 10.4 \pm 5.4 \mathrm{ng} / \mathrm{ml})$ and negative $(\mathrm{n}=40 ; 11 \pm 5.3$ $\mathrm{ng} / \mathrm{ml}$ ) blood cultures and the newborns in the control group $(\mathrm{p}=0.7, \mathrm{p}=0.2)$.

\section{DISCUSSION}

Demonstration of vitamin D receptors in immune system cells other than the extraskeletal system has drawn attention to the effects of vitamin D on the immune system, especially in association with sepsis, but the underlying pathological process has yet to be clarified. Vitamin $\mathrm{D}$ receptors are found in CD4 and CD8 T cells, B cells, neutrophils, 
Abdurrahman Avar Ozdemir et al.

Table-II: Maternal characteristics of the newborns.

\begin{tabular}{|c|c|c|c|}
\hline & $\begin{array}{c}\text { Sepsis Group }(n=51) \\
(\text { Mean } \pm S D)\end{array}$ & $\begin{array}{c}\text { Control Group }(n=56) \\
(\text { Mean } \pm S D)\end{array}$ & $p$ \\
\hline Age (year) & $30 \pm 6$ & $30 \pm 4$ & ${ }^{1} 0.93$ \\
\hline $\begin{array}{l}\text { Parity } \\
1 \\
2 \\
\geq 3\end{array}$ & $\begin{array}{l}23(45.1 \%) \\
18(35.3 \%) \\
10(19.6 \%)\end{array}$ & $\begin{array}{c}21(37.5 \%) \\
21(37.5 \%) \\
14(25 \%)\end{array}$ & ${ }^{2} 0.69$ \\
\hline $\begin{array}{l}\text { Socio-economic status } \\
\text { Low } \\
\text { Moderate } \\
\text { High }\end{array}$ & $\begin{array}{c}10(19.6 \%) \\
38(74.5 \%) \\
3(5.9 \%)\end{array}$ & $\begin{array}{l}9(16.1 \%) \\
42(75 \%) \\
5(8.9 \%)\end{array}$ & ${ }^{2} 0.77$ \\
\hline $\begin{array}{l}\text { Education level } \\
\text { Primary } \\
\text { Secondary } \\
\text { High }\end{array}$ & $\begin{array}{c}12(23.5 \%) \\
25(49 \%) \\
14(27.5 \%)\end{array}$ & $\begin{array}{c}8(14.3 \%) \\
28(50 \%) \\
20(35.7 \%)\end{array}$ & ${ }^{2} 0.41$ \\
\hline $\begin{array}{l}\text { Daily vitamin D intake } \\
\text { None } \\
\text { Insufficient } \\
\text { Sufficient }\end{array}$ & $\begin{array}{c}16(31.4 \%) \\
27(52.9 \%) \\
8(15.7 \%)\end{array}$ & $\begin{array}{l}16(28.6 \%) \\
19(33.9 \%) \\
21(37.5 \%)\end{array}$ & ${ }^{2} 0.02$ \\
\hline $\begin{array}{l}\text { Daily sunlight exposure } \\
\text { Yes } \\
\text { No }\end{array}$ & $\begin{array}{l}12(23.5 \%) \\
39(76.5 \%)\end{array}$ & $\begin{array}{l}13(23.2 \%) \\
43(76.8 \%)\end{array}$ & ${ }^{2} 0.06$ \\
\hline $\begin{array}{l}\text { Clothing style } \\
\text { Covered } \\
\text { Uncovered }\end{array}$ & $\begin{array}{l}35(68.6 \%) \\
16(31.4 \%)\end{array}$ & $\begin{array}{l}33(58.9 \%) \\
23(41.1 \%)\end{array}$ & ${ }^{2} 0.3$ \\
\hline $\begin{array}{l}\text { Season } \\
\text { Winter } \\
\text { Spring } \\
\text { Summer } \\
\text { Fall }\end{array}$ & $\begin{array}{c}27(52.9 \%) \\
11(21.6 \%) \\
5(9.8 \%) \\
8(15.7 \%)\end{array}$ & $\begin{array}{l}15(26.8 \%) \\
17(30.4 \%) \\
16(28.6 \%) \\
8(14.3 \%)\end{array}$ & ${ }^{2} 0.016^{*}$ \\
\hline
\end{tabular}

*Statistically significant at 0.05; 1: Student's t-test 2: Chi-squared test

macrophages and dendritic cells that play a role in the innate and adaptive immune response. Studies have shown that vitamin D has a suppressing effect on proliferation and antibody production of $\mathrm{T}$ and $\mathrm{B}$ cells as well as on the immune response of monocytes and dendritic cells. These findings suggest that vitamin D may play a role in autoimmunity. ${ }^{4,5,16}$ In studies on the innate immune system, vitamin $\mathrm{D}$ has been found to activate Toll-like receptors (TLR), which in turn induce the production of peptides such as cathelicidin and beta-defensin that have antimicrobial effects on bacteria, viruses and

Table-III: Laboratory findings of the newborns.

\begin{tabular}{lccc}
\hline & Sepsis Group & Control Group & $p$ \\
\hline Number of infants (n, \%) & $51(47.7 \%)$ & $56(52.3 \%)$ & \\
$25(\mathrm{OH}) \mathrm{D}(\mathrm{ng} / \mathrm{mL})($ mean $\pm \mathrm{SD})$ & $11.0 \pm 5.5$ & $13.8 \pm 10.6$ & ${ }^{1} 0.012^{*}$ \\
Ca $(\mathrm{mg} / \mathrm{dL})($ mean $\pm \mathrm{SD})$ & $8.7 \pm 1.2$ & $8.9 \pm 0.7$ & ${ }^{2} 0.36$ \\
P (mg/dL) (mean $\pm \mathrm{SD})$ & $5.9 \pm 0.9$ & $5.9 \pm 0.9$ & ${ }^{2} 0.74$ \\
ALP (U/L) (mean $\pm \mathrm{SD})$ & $163 \pm 58$ & $162 \pm 48$ & ${ }^{2} 0.91$ \\
\hline
\end{tabular}

25(OH)D: 25-hydroxyvitamin D; Ca: Calcium; P: Phosphorus; ALP: alkaline phosphatase.

*Statistically significant at 0.05; 1: Mann-Whitney U test, 2: Student's t test. 
Table-IV: Laboratory findings of the mothers.

\begin{tabular}{lccc}
\hline & Sepsis Group & Control Group & $p$ \\
\hline Number of mothers (n, \%) & $51(47.7 \%)$ & $56(52.3 \%)$ & \\
$25(\mathrm{OH}) \mathrm{D}(\mathrm{ng} / \mathrm{mL})($ mean $\pm \mathrm{SD})$ & $10.8 \pm 5.6$ & $14.9 \pm 10$ & ${ }^{1}<0.001^{*}$ \\
Ca (mg/dL) (mean $\pm \mathrm{SD})$ & $9.0 \pm 0.5$ & $8.8 \pm 0.4$ & ${ }^{2} 0.10$ \\
P (mg/dL) (mean $\pm \mathrm{SD})$ & $3.9 \pm 0.5$ & $4.3 \pm 1.0$ & ${ }^{2} 0.42$ \\
ALP (U/L) (mean $\pm \mathrm{SD})$ & $115 \pm 38$ & $116 \pm 30$ & ${ }^{2} 0.91$ \\
\hline
\end{tabular}

25(OH)D: 25-hydroxyvitamin D; Ca: Calcium; P: Phosphorus; ALP: alkaline phosphatase.

* Statistically significant at $0.01 ; 1$ : Mann-Whitney U test, 2 :Student's t test.

fungi. ${ }^{5,6}$ Early in vitro studies showed that Vitamin D had an inhibitory effect on Staphylococcus aureus, Streptococcus pyogenes, Klebsiella pneumoniae, and Escherichia coli, but its effect on fungal and parasitic infections remains unclear., ${ }^{4,17}$

In a meta-analysis, vitamin $\mathrm{D}$ deficiency was found to be a risk factor for infection and sepsis, resulting in increased mortality in adult patients in intensive care unit. $^{18}$ Madden et al. assessed admission vitamin D levels in critically ill children and found a high rate of vitamin D deficiency (40\%), which was also associated with increased disease severity at admission..$^{19}$ In contrast, Ponnarmeni et al. reported no association between low vitamin D levels and increased severity of illness in critically ill children with sepsis. ${ }^{20}$

Therearefew studies investigating the relationship between sepsis and vitamin $D$ in the neonatal period. Cetinkaya et al. reported a mean vitamin $\mathrm{D}$ level of $8.6 \mathrm{ng} / \mathrm{ml}$ in term newborns with EOS, as compared with $19 \mathrm{ng} / \mathrm{ml}$ in the control group. ${ }^{21}$ Similarly, Kanth et al. found significantly lower vitamin D levels in newborns with EOS than in the control group $(14.6 \mathrm{ng} / \mathrm{ml}$ vs. $26.4 \mathrm{ng} / \mathrm{ml}){ }^{22}$ Gamal et al. found not only significantly lower vitamin D levels in newborns with EOS as compared with controls, but also significant inverse correlations between vitamin D levels and all sepsis markers. ${ }^{23}$ Of note, all these studies reported a positive correlation between maternal and infant vitamin D levels. Our findings are consistent with the aforementioned studies of maternal and infant vitamin D levels in the context of newborn sepsis, but with a clear distinction. Previous studies assessed vitamin D levels only in newborns with EOS, whereas our study included all newborns with EOS and LOS. Although vitamin D levels of the newborns with EOS and LOS did not differ significantly, only newborns with EOS had significantly lower levels of vitamin D when compared with the controls. This finding may provide further insight into the course of newborn vitamin $\mathrm{D}$ levels in relation to EOS and LOS. Identification of significantly lower vitamin D levels in newborns with EOS and the correlation between maternal and newborn vitamin $\mathrm{D}$ levels might suggest that low vitamin D levels are likely to predispose newborns to EOS, whereas LOS is more likely to result from nosocomial and environmental factors other than vitamin D levels.

Among demographic features and birth-related factors, only male gender was significantly predominant among newborns with sepsis. It is well-known that male sex is a risk factor for sepsis in the neonatal period, which is thought to be associated with the suppressive effects of androgens on the immune system. ${ }^{24}$ As expected, compared with the control group, the newborns in the sepsis group had significantly higher CRP levels and significantly lower platelet counts.

As the mothers are the main source of neonatal vitamin D levels, its insufficiency or deficiency affects not only the mothers but also their babies. The Institute of Medicine emphasizes the need for at least 400-600 IU/day of vitamin D intake for pregnant women. In Turkey, a vitamin D supplementation program has been implemented, aiming to provide $1200 \mathrm{IU} /$ day vitamin $\mathrm{D}$ to all pregnant women. Before the introduction of the supplementation program, high rates of vitamin D deficiency had been reported among pregnant women, ranging between $50 \%$ and $94 \% .{ }^{25}$ In the current study, vitamin D deficiency was documented in $51.4 \%$ of the mothers and the rate of women who had regularly received vitamin D supplementation throughout pregnancy was as low as $27 \%$. Comparisons with respect to daily vitamin D intake during pregnancy and the seasonal distribution of deliveries showed that the mothers in the control group had higher rates of daily vitamin $\mathrm{D}$ intake and spring-summer deliveries, which corresponded well to significantly lower levels of maternal and newborn vitamin D levels in the sepsis group. 
Limitations of this study: The low socio-economic level of the participants and the exclusion of premature infants might have influenced maternal and newborn vitamin D levels. In addition, the number of patients in the LOS group was less than the EOS group.

In conclusion, despite the presence of few studies, the findings suggest that there may be an association between vitamin D deficiency and neonatal sepsis. In countries where vitamin D deficiency is common among pregnant women, the initiation of and effective implementation of vitamin D supplementation programs would be of particular value in reducing the health problems associated with vitamin D deficiency encountered not only among pregnant women but also among newborns. Yet, the level of vitamin $\mathrm{D}$ required for adequate immune function has yet to be clarified.

Conflict Interest: There are no Conflicts of Interest.

\section{REFERENCES}

1. Misra M, Pacaud D, Petryk A, Collett-Solberg PF, Kappy M. Vitamin D deficiency in children and its management: Review of current knowledge and recommendations. Pediatrics. 2008;122:398-417.

2. Mulligan ML, Felton SK, Riek AE, Bernal-Mizrachi C. Implications of vitamin D deficiency in pregnancy and lactation. Am J Obstet Gynecol. 2010;202:429.e1-9.

3. Wang TT, Nestel FP, Bourdeau V, Nagai Y, Wang Q, Liao J, et al. Cutting Edge: 1,25-Dihydroxyvitamin D3 Is a Direct Inducer of Antimicrobial Peptide Gene Expression. J Immunol. 2004;173(5):2909-2912.

4. Kempker JA, Tangpricha V, Ziegler TR, Martin GS. Vitamin $\mathrm{D}$ in sepsis: from basic science to clinical impact. Crit Care. 2012;16(4):316.

5. Aranow C. Vitamin D and the Immune System. J Investig Med. 2011;59(6):881-886. doi: 10.231/JIM.0b013e31821b8755.

6. Jeng L, Yamshchikov AV, Judd SE, Blumberg HM, Martin GS, Ziegler TR, et al. Alterations in vitamin D status and anti-microbial peptide levels in patients in the intensive care unit with sepsis. J Transl Med. 2009;7:28. doi: 10.1186/14795876-7-28.

7. Aydemir G, Cekmez F, Kalkan G, Fidanci MK, Kaya G, Karaoglu A, et al. High serum 25-hydroxyvitamin D levels are associated with pediatric sepsis. Tohoku J Exp Med. 2014;234(4):295-298.

8. Esposito S, Lelii M. Vitamin D and respiratory tract infections in childhood. BMC Infect Dis. 2015;15:487. doi: 10.1186/s12879-015-1196-1.

9. Camacho-Gonzalez A, Spearman PW, Stoll BJ. Neonatal infectious diseases: evaluation of neonatal sepsis. Pediatr Clin North Am. 2013;60(2):367-389. doi: 10.1016/j. pcl.2012.12.003.

10. Dessi A, Pravettoni C, Ottonello G, Birocchi F, Cioglia F, Fanos V. Neonatal sepsis. J Pediatr Neonat Individual Med. 2014;3(2):e030273. doi: 10.7363/030273.

11. Shah BA, Padbury JF. Neonatal sepsis: An old problem with new insights. Virulence. 2014;5(1):170-178. doi: 10.4161/viru.26906.
12. Manroe BL, Weinberg AG, Rosenfeld CR, Browne R. The neonatal blood count in health and disease. I.Reference values for neutrophilic cells. J Pediatr. 1979;95:89-98.

13. Rodwell RL, Leslie AL, Tudehope DI. Early diagnosis ofneonatal sepsis using a hematological scoring system. J Pediatr. 1988;112:761-767.

14. Gitto E, Karbownik M, Reiter JR, Tan DX, Cuzzocrea $\mathrm{S}$, Chiurazzi P, et al. Effects of melatonin treatment in septic newborns. Pediatr Res. 2001;50:756-760. doi: 10.1203/00006450-200112000-00021

15. Munns CF, Shaw N, Kiely M, Specker BL, Thacher TD, Ozono K, et al. Global Consensus Recommendations on Prevention and Management of Nutritional Rickets. J Clin Endocrinol Metab. 2016;101:394-415.

16. Kempker JA, Tangpricha V, Ziegler TR, Martin GS. Vitamin $\mathrm{D}$ in sepsis: from basic science to clinical impact. Crit Care. 2012;16(4):316. doi: 10.1186/cc11252.

17. Youssef DA, Miller CW, El-Abbassi AM, Cutchins DC, Cutchins C, Grant WB, et al. Antimicrobial implications of vitamin D. Dermatoendocrinol. 2011;3(4):220-229.

18. de Haan K, Groeneveld AB, de Geus HR, Egal M, Struijs A. Vitamin D deficiency as a risk factor for infection, sepsis and mortality in the critically ill: systematic review and meta-analysis. Crit Care. 2014;18(6):660. doi: 10.1186/ s13054-014-0660-4.

19. Madden K, Feldman HA, Smith EM, Gordon CM, Keisling SM, Sullivan RM, et al. Vitamin D Deficiency in Critically Ill Children. Pediatrics. 2012;130(3):421-428. doi: 10.1542/ peds.2011-3328.

20. Ponnarmeni S, Kumar Angurana S, Singhi S, Bansal A, Dayal D, Kaur R, et al. Vitamin D deficiency in critically ill children with sepsis. Paediatr Int Child Health. 2016;36(1):15-21. doi: 10.1179/2046905515Y.0000000042.

21. Cetinkaya M, Cekmez F, Buyukkale G, Erener-Ercan $\mathrm{T}$, Demir F, Tunc $\mathrm{T}$, et al. Lower vitamin D levels are associated with increased risk of early-onset neonatal sepsis in term infants. J Perinatol. 2015;35(1):39-45. doi: 10.1038/ jp.2014.146.

22. Kanth SU, Reddy KA, Abhishek GS. Association between vitamin $\mathrm{D}$ levels and early onset sepsis in infants: a prospective observational study. Int J Contemp Pediatr. 2016;3(4):1189-1192. doi: 10.18203/2349-3291.ijcp20163168.

23. Gamal TS, Madiha AS, Hanan MK, Abdel-Azeem ME, Marian GS. Neonatal and Maternal 25-OH Vitamin D Serum Levels in Neonates with Early-Onset Sepsis. Children (Basel). 2017;9:4(5). pii: E37. doi: 10.3390/children4050037.

24. Albers MJ, de Gast-Bakker DA, van Dam NA, Madern GC, Tibboel D. Male sex predisposes the newborn surgical patient to parenteral nutrition-associated cholestasis and to sepsis. Arch Surg. 2002;137(7):789-793.

25. Vitamin D Deficiency in Pregnant Women and Their Infants. Ozdemir AA, Ercan Gundemir Y, Kucuk M, Yildiran Sarici D, Elgormus Y, Cag Y, Bilek G. J Clin Res Pediatr Endocrinol. 2018;10(1):44-50. doi: 10.4274/jcrpe.4706.

\section{Authors Contribution:}

AAO: Designed and did data collection, writing \& editing of manuscript.

YC: Did data collection statistical analysis and manuscript writing. 